\title{
PERAN WORLD TRADE ORGANIZATION (WTO) DALAM MENYELESAIKAN SENGKETA PERDAGANGAN INTERNASIONAL
}

\author{
Rubiyanto *
}

\begin{abstract}
International trade disputes that occur require an international institution to supervise and become the party that has the role to solve the problem. WTO as a world trade organization has an important role in efforts to resolve international trade disputes. Based on the discussion it can be concluded that the WTO as a world trade organization has an important role in resolving international trade disputes. Procedure for resolving international trade disputes. Procedures for resolving international trade disputes within the WTO framework can be carried out through the consultation stage Panels Formation, Panel procedures, Adoption of panels report, Appellate review, and Implementation.
\end{abstract}

Keywords: role, world trade organization, international trade dispute

\section{PENDAHULUAN}

World Trade Organization (WTO) merupakan organisasi dunia di bidang perdagangan yang sangat dominan dalam membentuk arah regulasi perdagangan internasional. Setiap regulasi yang dikeluarkan oleh WTO wajib ditaati oleh setiap negara anggota, terutama mengenai disiplin perdagangan internasional yang dikeluarkannya. Dikemukakan oleh Dian Ediana RAE bahwa aturan main WTO sekarang telah menjadi elemen penting dalam penerapan strategi perekonomian setiap negara secara umum, dan khususnya strategi dalam perdagangan internasional nya. ${ }^{\circ}$

Dominasi WTO dalam mengatur sistem perdagangan internasional tidak dapat dilepaskan dari pertumbahan dan perkembangan ekonomi antar bangsabangsa yang semakin cepat dan dinamis.

* Rubiyanto adalah Pengajar di Fakultas Hukum Universitas 17 Agustus 1945 Semarang dapat dihubungi melalui email : rubiyanto.151161@ gmail.com

1 Dian Ediana RAE, 2010, Pengantar Singkat World Trade Organization (WTO), PPS MIH Untar: Jakarta, hlm. 1
Pesatnya pertumbuhan ekonomi negaranegara baik negara-negara Asean, USA, Uni Eropa, dan lain-lain menyebabkan tingkat persaingan dalam hubungan dagang semakin tinggi. Arus globalisasi yang semakin cepat berjalan sekarang ini membuat perdagangan bebas menjadi tidak terbendung lagi. ${ }^{2}$

Negara-negara anggota WTO harus menyesuaikan peraturan nasionalnya dengan ketentuan-ketentuan yang ada dalam persetujuan-persetujuan WTO. Perdagangan internasional yang didasari oleh perjanjian bilateral, multilateral, dan konvensi-konvensi internasional meng haruskan setiap anggota WTO untuk mempersiapkan diri dalam menghadapi persaingan terutama untuk melindungi kepentingan industri dalam negeri.

Praktek di lapangan menunjukkan bahwa kegiatan para pelaku perdagangan internasional suatu saat dapat menimbulkan terjadinya perselisihan yang melahirkan sengketa dalam perdagangan inter nasional. $^{3}$

\footnotetext{
2 Syahmin Ak,2006, Hukum Dagang Internasional (Dalam Kerangka Studi Analitis), Raja Grafindo: Jakarta, hlm. 357 3 Syahmin Ak, Op. Cit., hlm. 228
} 
Sengketa dalam perdagangan internasional pada umumnya diselesaikan melalui negosiasi terlebih dahulu, Jika cara penyelesaian ini gagal atau tidak berhasil, barulah ditempuh cara-cara lainnya, seperti penyelesaian melalui pengadilan atau arbitrase. ${ }^{4}$

Sengketa perdagangan inter nasional yang terjadi, memerlukan suatu lembaga internasional untuk mengawasi dan menjadi pihak yang berperan untuk menyelesaikan persoalan tersebut. World Trade Organization memiliki peran yang penting dalam upaya menyelesaikan sengketa perdagangan internasional, tidak sekedar mengawasi sebagaimana GATT (General Agreements on Tariff and Trade), antara lain mengawasi praktik-praktik perdagangan internasional dengan secara regular meninjau kebijaksanaan perdagang an negara anggotanya dan melalui prosedur notifikasi. World Trade Organization juga berperan sebagai forum dalam menyelesai kan sengketa perdagangan internasional yang timbul. ${ }^{5}$

\section{Pembahasan}

\section{Sejarah Singkat World Trade Organization}

Organisasi Perdagangan Dunia (World Trade Organization) adalah organisasi internasional yang mengawasi banyak persetujuan yang mendefinisikan "aturan perdagangan" di antara anggotanya. WTO secara resmi berdiri sejak 1 Januari 1995 merupakan organisasi perdagangan internasional yang didirikan sebagai salah satu hasil kesepakatan dari perundingan liberalisasi perdagangan ke delapan yang dikenal dengan Putaran Uruguay (Uruguay Round) menggantikan GATT. GATT merupakan persetujuan setelah Perang

4 Huala Adolf, 2005, Hukum Perdagangan Internasional, Raja Grafindo Persada: Jakarta, hlm. 191

5 Syahmin AK.,Op.Cit., hlm. 235
Dunia II untuk meniadakan hambatan perdagangan internasional. Prinsip dan persetujuan GATT diambil oleh WTO, yang bertugas untuk mendaftar dan mem perluasnya.

World Trade Organization merupakan pelanjut Organisasi Perdagangan Internasional/International Trade Organization (ITO). International Trade Organization disetujui oleh PBB dalam Konferensi Dagang dan Karyawan di Havana pada Maret 1948, namun ditutup oleh Senat AS. World Trade Organization bermarkas di Jenewa, Swiss. Pada Juli 2008 organisasi ini memiliki 153 negara anggota. Seluruh anggota WTO diharuskan memberikan satu sama lain status negara paling disukai, sehingga pemberian keuntungan yang diberikan kepada sebuah anggota WTO kepada negara lain harus diberikan ke seluruh anggota WTO. Lahirnya World Trade Organization telah menghasilkan berbagai ketentuan yang mewarnai perdagangan internasional, menempatkan organisasi ini sebagai sosok yang berpengaruh dalam perdagangan internasional tentunya termasuk Indonesia. ${ }^{6}$

Putaran Uruguay membawa perubahan besar dan memberikan hasil yang nyata bagi sistem perdagangan dunia, dalam putaran ini substansi perundingan dibagi dalam empat kelompok permasalah an yang terdiri dari: perluasan akses pasar, penyempurnaan aturan main dalam GATT, penyempurnaan institusi GATT, dan isu baru yang belum dibahas dalam GATT di bidang jasa, perlindungan hak kekayaan intelektual dan kebijakan investasi yang berpengaruh pada kebijakan internasional. ${ }^{7}$

Perangkat hukum internasional yang mengatur hubungan dagang antar Negara terkandung dalam dokumen GATT yang ditandatangani Negara negara tahun 1947, dan mulai diberlakukan pada tahun

6 Soedjono Dirdjosisworo, 2006, Pengantar Hukum Dagang Internasional, Refika Aditama: Bandung, hlm. 133

7 Dian Ediana RAE, Op.Cit., hlm. 1 
1948. Kemudian aturan-aturan dalam GATT 1947 diintegrasikan ke dalam sistem WTO, yang tidak hanya mengatur perdagangan barang, tetapi juga perdagang an jasa, masalah hak milik intelektual, dan aspek-aspek penanaman modal yang terkait. $^{8}$

Sejak tahun 2003 telah berlaku era pasar bebas untuk perdagangan bebas AFTA (Asean FreeTrade Area) dan tahun 2010 untuk Negara-negara APEC (Asia Pasific Economic Coperation) yang Indonesia juga turut di dalamnya dan secara keseluruhan Negara anggota WTO pada tahun 2020. ${ }^{9}$ World Trade Organization adalah suatu lembaga perdagangan multilateral yang permanen. Sebagai suatu organisasi permanen, peranan WTO akan lebih kuat daripada GATT. Hal ini secara langsung tercermin dalam struktur organisasi dan sistem pengambilan keputusan. World Trade Organization memiliki status sebagai organ khusus PBB seperti halnya IMF (International Monetary Fund) dan IBRD (International Bank for Reconstructuries and Development). World Trade Organization memiliki fungsi mendukung pelaksanaan administrasi dan menyelenggarakan persetujuan yang telah dicapai untuk mewujudkan sasaran.

World Trade Organization sebagai suatu organisasi internasional memegang peranan penting dalam mengatur masalah perdagangan dunia dan didirikan dengan maksud untuk menciptakan kesejahteraan Negara melalui serangkaian aturan perjanjian perdagangan multilateral yang adil dan transparan serta menjaga keseimbangan kepentingan semua Negara, baik Negara maju maupun Negara berkembang termasuk Negara Least Developing Countries (LDC's). Tujuan mencapai kesejahteraan bersama tersebut dituangkan lebih lanjut dalam undangundang pendirian WTO (agreement of

8 Syahmin AK., Op.Cit., hlm. 12. 9 Ibid., Hlm. 15
World Trade Organization establishing) yang isinya menegaskan secara spesifik mengenai tujuan, fungsi, dan struktur kelembagaan yang dapat mendukung tercapainya tujuan WTO. ${ }^{10}$

World Trade Organization dalam menjalankan fungsinya dilengkapi dengan sejumlah organ sebagai berikut: ${ }^{11}$

a. Ministerial Conference

Merupakan organ utama yang keanggotaannya adalah seluruh Negara anggota dan akan melakukan pertemuan sedikitnya dua tahun sekali.

b. General Council

Organ ini terdiri dari utusan Negaranegara anggota yang melaksanakan fungsi-fungsi ministerial conference pada waktu-waktu di antara pertemuan pertemuan ministerial conference, general council juga akan melaksana kan tugas yang dibebankan padanya oleh perjanjian ini.

c. Council Trade in Goods (Dewan Perdagangan Jasa). Badan ini berada di bawah General Council yang bertugas memantau pelaksanaan persetujuan yang dicapai di bidang perdagangan jasa.

d. Council for Trade Related Aspect of International Property Right (Dewan untuk Aspek Dagang yang terkait dengan HAKI). Badan ini di bawah General Council yang bertujuan memantau pelaksanaan persetujuan di bidang aspek perdagangan HAKI.

e. Dispute Setlement Body (Badan Penyelesaian Sengketa) Badan ini berada di bawah Ministerial Conference yang menyelenggarakan forum pelaksanaan penyelesaian sengketa perdagangan yang timbul di antara Negara anggota.

f. Trade Policy Review Body (Badan Peninjauan Kebijaksanaan Perdagang an). Badan ini berada di bawah Ministerial Conference yang bertujuan

10 Ibid., hlm. 4

11 Syahmin AK., Ibid., hlm. 53-55 
menyelenggarakan mekanisme pemantauan kebijakan di bidang perdagangan.

\section{Penyelesaian Sengketa Perdagangan Internasional}

Penyelesaian sengketa dalam hukum perdagangan internasional pada prinsipnya tidak berbeda dengan hukum penyelesaian sengket. Pada umumnya penyelesaian tersebut meliputi: ${ }^{12}$

a. Negosiasi

Negosiasi adalah cara penyelesaian sengketa yang paling dasar dan yang paling tua digunakan. Secara umum negosiasi dapat diartikan sebagai suatu upaya penyelesaian sengketa para pihak tanpa melalui proses peradilan dengan tujuan mencapai kesepakatan bersama atas dasar kerjasama yang lebih harmonis dan kreatif, disini para pihak berhadapan langsung secara seksama dalam mendiskusikan permasalahan yang dihadapi dengan cara kooperatif dan saling terbuka. ${ }^{13}$ Negosiasi melibatkan komunikasi dua atau lebih pihak-pihak yang berkepentingan untuk mencapai suatu kesepakatan agar mereka dapat bekerja sama. $^{14}$

b. Mediasi

Mediasi atau dalam bahasa Inggris disebut dengan mediation adalah penyelesaian sengketa dengan menengahi, sedangkan mediator adalah orang yang menjadi penengah. ${ }^{15}$ Mediasi adalah upaya penyelesaian sengketa para pihak dengan kesepakatan bersama melalui mediator

12 Huala Adolf, Op.Cit., hlm. 200

13 Joni Emerzon,2000, Alternatif Penyelesaian Sengketa di Luar Pengadilan, Gramedia Pustakatama: Jakarta, hlm 44

14 Yudha Pandu,2004, Klien \& Advokat dalam Praktek, Indonesia Legal Center Fublising: Jakarta, hlm 133

15 John M. Echols dan Hasan Shadily, 1990, Kamus Inggris Indonesia, cet. XXV, Gramedia Pustaka Utama: Jakarta, hlm 377 yang bersikap netral dan tidak membuat keputusan atau kesimpulan bagi para pihak tetapi menunjang fasilitator atau terlaksananya dialog antar pihak dengan suasana keterbukaan, kejujuran dan tukar pendapat untuk tercapainya mufakat.

c. Konsiliasi

Konsiliasi memiliki kesamaan dengan mediasi.Kedua cara ini adalah melibatkan pihak ketiga untuk menyelesaikan sengketanya secara damai. Konsiliasi dan mediasi sulit untuk dibedakan.

d. Arbitrase

Arbitrase adalah penyerahan sengketa secara sukarela kepada pihak ketiga yang netral. Pihak ketiga ini bisa individu, arbitrase terlembaga atau arbitrase sementara (ad hoc). Badan arbitrase dewasa ini sudah semakin populer. Dewasa ini arbitrase semakin banyak digunakan dalam menyelesai kan sengketa-sengketa dagang nasional maupun internasional.

e. Pengadilan (Nasional dan Inter nasional)

Metode yang memungkinkan untuk menyelesaikan sengketa selain caracara tersebut di atas adalah melalui pengadilan nasional atau internasional. Penggunaan cara ini biasanya di tempuh apabila cara cara penyelesaian yang ada ternyata tidak berhasil.

\section{Peran World Trade Organization} (WTO) Dalam Menyelesaikan S e ngke t a P e rd a gangan Internasional

Sistem Penyelesaian Sengketa World Trade Organization (WTO)/Dispute Settlement Understanding (DSU) adalah tulang punggung dari rejim perdagangan multilateral saat ini. Sistem ini diciptakan oleh para Negara anggota WTO pada saat Uruguay Round dengan harapan untuk menciptakan suatu sistem yang kuat dan 
dapat mengikat semua pihak dalam rangka menyelesaikan sengketa perdagangan dalam kerangka WTO.

Negara-negara anggota melalui sistem penyelesaian sengketa ini diharapkan dapat mematuhi peraturanperaturan yang disepakati dalam WTO Agreement. Sistem penyelesaian sengketa ini juga dinilai sebagai kontribusi unik dari WTO terhadap kestabilan perekonomian global. Sistem penyelesaian sengketa WTO dibentuk sebagai pembaruan dari sistem penyelesaian sengketa General Agreement on Tariff and Trade (GATT) yang sebelumnya ada. Dengan sistem penyelesaian sengketa WTO diharapkan akan diperoleh kestabilan dan perkiraan peraturan perdagangan internasional yang berpihak pada kegiatan bisnis, petani, pekerja dan konsumen dari seluruh dunia. ${ }^{16}$

Sistem penyelesaian sengketa WTO memainkan peran penting dalam mengklarifikasi dan penegakan kewajiban anggota dalam WTO Agreement. Penyelesaian sengketa memang bukan kegiatan utama dalam kinerja organisasi WTO, namun penyelesaian sengketa adalah bagian yang sangat penting dalam kenyataan kinerja organisasi. Penyelesaian sengketa WTO juga menjadi perangkat penting dalam manajemen negara anggota WTO dan kaitannya dengan hubungan ekonomi yang luas. ${ }^{17}$

Penyelesaian sengketa menjadi tanggung jawab Badan Penyelesaian Sengketa (Dispute Settlement Body/DSB) yang merupakan penjelmaan dari Dewan Umum (General Council/GC). DSB adalah satu-satunya badan yang memiliki otoritas membentuk Panel yang terdiri dari para ahli yang bertugas menelaah kasus. DSB dapat juga menerima atau menolak keputusan Panel atau keputusan pada tingkat banding. DSB tersebut memonitor pelaksanaan putusan-putusan dan rekomendasi serta memiliki kekuasaan atau wewenang untuk

16 Ibid.

17 Ibid. mengesahkan retaliasi jika suatu negara tidak mematuhi suatu putusan. ${ }^{18}$

Suatu negara apabila melanggar aturan WTO dengan menetapkan aturan yang tidak konsisten dengan WTO, maka negara tersebut harus segera mengoreksi kesalahannya dengan menyelaraskan aturannya dengan aturan WTO. Apabila negara tersebut masih melanggar aturan WTO, maka harus membayar kompensasi atau dikenai "retaliasi". Biasanya kompensasi atau retaliasi diterapkan dalam bentuk konsesi atau akses pasar. Walaupun suatu kasus sudah diputuskan, masih banyak hal yang harus dilakukan sebelum sanksi perdagangan diterapkan. ${ }^{19}$

Tergugat pada tahap ini harus menyelaraskan kebijakannya dengan rekomendasi atau keputusan DSB. Persetujuan WTO mengenai penyelesaian sengketa menetapkan bahwa "tindakan yang cepat dalam hal mematuhi rekomendasi atau putusan DSB sangat penting untuk menjamin bahwa putusan penyelesaian tersebut efektif dan menguntungkan seluruh anggota WTO. Negara yang kalah sengketa harus mengikuti rekomendasi yang disebutkan dalam laporan Panel (panel report) atau laporan banding (appelate Body report).

Secara prinsipil, sanksi diterapkan pada bidang yang sama dengan bidang yang disengketakan dan apabila sanksi tersebut tidak dapat dilaksanakan atau tidak efektif, maka sanksi dapat diterapkan dalam sektor yang lain, dalam satu persetujuan yang sama. Selanjutnya, sekiranya masih juga belum dilaksanakan atau belum efektif, dan jika keadaannya cukup serius, tindakan dapat diambil di bawah persetujuan WTO lain. Maksudnya adalah untuk memperkecil kesempatan merambatnya tindakan tersebut ke dalam bidang-bidang yang tidak ada hubungannya dengan bidang tersebut, sekaligus agar menjamin agar tindakan tersebut efektif. Dalam setiap kasus, DSB

18 Ibid.
19 Ibid. 
mengawasi pelaksanaan putusan yang telah disahkan. Kasus-kasus yang masih dalam proses tetap menjadi agenda DSB sampai berhasil diselesaikan. ${ }^{20}$

Prosedur penyelesaian sengketa perdagangan internasional di dalam kerangka WTO, dapat dilakukan melalui tahapan sebagai berikut: ${ }^{21}$

a. Konsultasi(Concultations)

Tujuan dari mekanisme penyelesaian sengketa dagang di WTO adalah untuk menguatkan solusi yang positif terhadap sengketa.

b. Pembentukan Panels (Establishment Panels)

Jika suatu anggota tidak memberikan jawaban untuk meminta diadakan konsultasi dalam waktu 10 hari atau jika konsultasi gagal untuk diselesaikan dalam waktu 60 hari, penggugat dapat meminta ke DSB untuk membentuk suatu panel untuk menyelesaikan masalah pembentukan panel. Panel harus segera disusun dalam waktu 30 hari pembentukan.

c. Prosedur-prosedur Panel (Panels Procedures)

Yaitu periode dimana panel melaksanakan pengujian masalah, selanjutnya term of reference dan komposisi panel disetujui, kemudian panel memberikan laporan kepada pihak-pihak yang bersengketa tidak boleh lebih dari 6 bulan.

d. Penerimaan Laporan Panel ke DSB (Adoption of Panels Report)

Prosedur WTO menunjukkan bahwa laporan panels harus diterima oleh DSB dalam waktu 60 hari dari pengeluaran. Jika tidak, satu pihak memberitahukan keputusannya untuk menarik atau consensus terhadap pengesahan laporan.

20 Ibid.

21 Syahmin AK.,2005, Peranan Hukum Kontrak Internasional dalam Era Pasar Bebas, (Diktat Perkuliahan), Fakultas Hukum Univ. Sjakhyakirti: Palembang, hlm. 54 e. Peninjauan Kembali (Appellate Review)

Mekanisme penyelesaian sengketa di WTO memberikan kemungkinan penarikan terhadap salah satu pihak dalam berlangsungnya suatu panel. Semua permohonan akan didengar oleh suatu Badan Peninjau (appellate body) yang dibentuk oleh DSB

f. Implementasi (Implementation) Kebijakan menekankan bahwa peraturan dari DSB sangat penting agar mencapai resolusi yang efektif dari persengketaan-persengketaan yang bermanfaat untuk semua anggota. Pada pertemuan DSB berlangsung dalam waktu tiga puluh hari dari adopsi panel, pihak yang bersangkutan harus menyatakan niat untuk menghargai implementasi dari rekomendasirekomendasi. Bila hal itu tidak berguna untuk segera menyetujui, anggota akan diberikan suatu periode waktu yang beralasan yang ditentukan oleh DSB (Disputes Settlement Body).

Ketentuan-ketentuan WTO mengenai penyelesaian sengketa bagi Negara berkembang pada dasarnya sama dengan ketentuan-ketentuan yang diterapkan bagi Negara maju, namun ada beberapa ketentuan khusus yang hanya diberlakukan bagi penyelesaian sengketa Negara berkembang. ${ }^{22}$

Salah satu contoh apabila dalam tahap konsultasi gagal menyelesaikan perselisihan dalam waktu 60 hari sejak permohonan konsultasi diterima, para pihak dapat bersepakat untuk memper panjang jangka waktunya. Apabila jangka waktu yang ditetapkan 60 hari telah habis masa berlakunya, sedangkan para pihak yang berkonsultasi belum dapat tercapai kesepakatan bahwa konsensus telah berakhir, ketua DSB harus memutuskan perpanjangan waktu tersebut. Para anggota

22 Syahmin AK.,2008, Hukum Internasional Publik, Jilid 3, PT. Bina Cipta: Bandung, hlm. 314 
harus memberikan perhatian khusus kepada Negara berkembang bila penyebab sengketanya adalah kebijaksanaan yang diambil oleh Negara berkembang.

\section{Kesimpulan}

Berdasarkan uraian di atas dapat disimpulkan bahwa World Trade Organization sebagai organisasi perdagangan dunia memiliki peran yang penting dalam penyelesaian sengketa perdagangan internasional. Prosedur penyelesaian sengketa perdagangan internasional di dalam kerangka WTO, dapat dilakukan melalui tahapan-tahapan berikut: Konsultasi (Concultations), Pembentukan Panels (Establishment Panels), Prosedur-prosedur Panel (Panels Procedures), Penerimaan Laporan Panel ke DSB (Adoption of Panels Report), Peninjauan Kembali (Appellate Review), Implementasi (Implementation).

\section{Saran}

World Trade Organization sebagai organisasi perdagangan dunia memiliki peran yang penting dalam penyelesaian sengketa perdagangan internasional, oleh karena itu dalam menyelesaikan sengketa perdagangan baik antar negara dengan negara, negara dengan badan usaha, atau badan usaha dengan badan usaha benarbenar mempertimbangkan asas keadilan masyarakat internasional dan asas teritorial terkait kebijakan suatu negara.

\section{DAFTAR PUSTAKA}

Dian Ediana RAE, 2010, Pengantar Singkat World Trade Organization (WTO) PPS MIH Untar: Jakarta

Huala Adolf, 2005, Hukum Perdagangan Internasional, Raja Grafindo Persada: Jakarta

John M. Echols dan Hasan Shadily,1990, Kamus Inggris Indonesia, cet. XXV, Gramedia Pustaka Utama: Jakarta

Joni Emerzon,2000, Alternatif Penyelesaian Sengketa di Luar Pengadilan, Gramedia Pustakatama: Jakarta

Soedjono Dirdjosisworo,2006, Pengantar Hukum Dagang Internasional, Refika Aditama: Bandung

Syahmin AK.,2005, Peranan Hukum Kontrak Internasional dalam Era Pasar Bebas, (Diktat Perkuliahan), Fakultas Hukum Univ. Sjakhyakirti: Palembang

Syahmin Ak,2006, Hukum Dagang Internasional (Dalam Kerangka Studi Analitis), Raja Grafindo: Jakarta

Syahmin AK.,2008, Hukum Internasional Publik, Jilid 3, PT. Bina Cipta: Bandung

Yudha Pandu,2004, Klien \& Advokat dalam Praktek, Indonesia Legal Center Fublising: Jakarta

Undang-Undang Republik Indonesia Nomor 7 Tahun 1994 Tentang ratifikasi Argreement Establishing the World_Trade Organization (LN. 1994 No. 57, TLN. No. 3564), berkewajiban berperan aktif dalam 